\title{
Research on Reform Paths of Journalism Education under the Background of Media Convergence
}

\author{
Xiaojuan Wu, a , Wenna Cui ${ }^{1, b}$ \\ ${ }^{1}$ Nanchang Institute of Science \& Technology, Nanchang, 330108, China

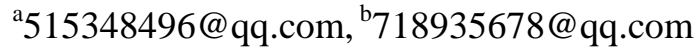

Keywords: journalism education; media convergence; reform paths

\begin{abstract}
The arrival of the era of media convergence has brought great changes to the media industry. The change has put forward new demands on the professionalism of journalists. The traditional journalism teaching concept, content and mode have different degrees of defects, which are difficult to adapt to the development trend of media convergence. This paper discusses the reform paths of journalism education under the background of media convergence, including updating education concept, enriching curriculum content and increasing practice teaching to provide some references for the relative researchers.
\end{abstract}

\section{Introduction}

Media integration refers to the trend of multi-functional integration of various media. The imagination of media integration is more concentrated on the integration of traditional media, such as television and newspapers [1]. This intention is more inclined to technical integration. Media organizations hope to gain more advertising share through media integration. The media organizations make news products with different ways of reporting, to pursue the best effect of communication. For example, the radio station set up a website to supplement the visual information for its own programs. Nowadays, the content created by the public is increasingly being used by professional media. Meanwhile, the popular social networking services also have a great impact on people's information sharing, which greatly changed the relationship between the public and the mainstream media. The public has become more and more involved in the media's agenda setting. We have been living in the era of media convergence. There are many changes in this era. Communication, storytelling and information technology are slowly shaping our way of life. Of course, it also includes how we produce information, disseminate information, consume information and learn information. There are only a few media management and management specialties in the Department of Journalism and communication in China, and most of them have only set up several related courses. Teaching contents and goals are lagging practice, and media convergence is also rising in the industry. Its development rule and demand for talents haven't been reflected in professional education. All media journalists must be proficient in the characteristics of all kinds of media, know the possibility of technology development for communication, and use various technologies to make communication content better [2].

\section{Main Deficiencies of Current Journalism Education}

\subsection{Backward Teaching Concept}

Now the media industry has shown a trend of rapid development, team cooperation and media integration trend of journalism which requires a trend which cannot be halted, graduates can after several years of professional education, to adapt to the media environment, the news dissemination of early and late to work. But from a practical point of view, most of colleges and universities education journalism professional setting is not clear still cannot keep up with the development of the times, the 
students need the contents of teaching content and the actual news work is different, which leads to many journalism students, in the work environment into the news, after becoming a the media people, really hard to adapt to the environment, there has been some knowledge and skills to work and need effective docking. The lag of news education in Colleges and universities is closely related to the lack of scientific guidance for the idea of running a school. Because of the late start, the news department of the discipline construction in the initial stage tend to key comprehensive university as the reference, slavishly copied their education program and curriculum system. In the development stage, because the target location is not clear, the intensity and scope of the adjustment is still limited, and the whole category is not divorced from traditional disciplines and media types. Vague training objectives and the traditional curriculum system caused by the gap between News Teaching in Colleges and universities and the new era of social demand, resulting in media student loss in the face of fusion news production. The goal of talent training in journalism departments in It is relatively broad and monotonous, and the coverage cannot cover the needs. With the rapid development of the new media and the integration of the media, the development of the era of the media cannot be synchronized with the industry and the industry, which is not in line with the reality of the development of the news industry.

\subsection{Obsolete Teaching Content}

Now the implementation of media convergence media industry represents the general trend, but many of our universities in professional settings are relatively lagging, many university journalisms for many years has been used to smell the traditional teaching methods, but no news industry rapidly, the need to constantly change the teaching content, to keep pace with the times. Many journalism majors do not have the relevant educational content of media integration, but only transfer theoretical knowledge to students, and do not present a true media environment for students. In fact, for journalism education, many colleges and universities of our country have the wrong priorities, most schools that should be the first good news for students education, let the students to face the real media environment, but in fact, the unique nature of news communication and journalism in university teaching constantly the basis of the teaching content based on the media development, so as to truly cultivate comprehensive talent service level strong outstanding professional skills, get rid of the negative impact of one-sided knowledge to journalism. The fusion of media. Need news subject to cooperate. However, journalism stubbornly adhering to the fine tradition of the subject. According to the news media platform from media convergence, it means that the mode of transmission is no longer the newspapers, radio and television, but through the Internet platform, put together a variety of modes of transmission, increase the depth of the news. The news later extended tracking, transparent audience attitude on the news. Therefore, it is obviously impossible to match the actual situation according to the media transmission. In addition, the problem of a single course and obsolete main content is also common in the teaching of journalism [3].

\subsection{Antiquated Teaching Model}

In the new media age of media integration, the news personnel should not only have a perfect structure of knowledge theory, but also have strong practical ability. And news dissemination itself is also a very strong professional and practical. Therefore, in the process of journalistic general education, we should pay equal attention to both theory and practice, encourage students to participate in social practice and professional practice, and promote the all-round development of students. Throughout China University journalism education, most of the news has emerged on the status of professional classroom between teachers and students is extremely unbalanced state teachers always occupy the dominant position of students in the classroom, and the theory of indoctrination education, students do is sit on the seat listen, the passive acceptance of knowledge. Not only that, the smell of professional show surface features and simplification in the curriculum, such as radio and television professional students, all the contents of the study are cannot do without the broadcast television content, and other media have little contact, not even lead to radio and television professional students only know this one the spreading form of knowledge, which is weak 
in practice greatly. For example, journalism majors only learn about news writing and other contents. They do not involve in news communication and news production. This greatly weakens the competitiveness of this part of students after graduation. When the journalism students get to their jobs, they are still unable to get more professional knowledge than graduates of politics, law, economics and other specialties. At present, the news General Education in our country is difficult to take the way to build the news General Education Based on the humanities and social sciences. This mode of education is obviously a kind of biased journalism education, which does not conform to the goal of cultivating compound talents [4].

\section{Reform Countermeasures of Journalism Education under the Background of Media Convergence}

\subsection{Update Education Concept}

The idea of news education should follow the pace of the times and keep pace with the times. The reform of news education is no longer a simple adjustment of teaching curriculum and innovative teaching mode, the key is to establish a new consciousness of large communication and all media. In the context of media integration, journalism education cannot be simply understood as the dissemination of news teaching, as the main place to cultivate professional talents of journalism, great changes of journalism education colleges should keenly aware of the press the time of educational aim, teaching ideas to make corresponding adjustment, and constantly innovate education concept, education system and journalism education mode of thinking, the school of education, self-education and social practice education of organic integration, implementation of three-in-one education concept, and constantly open up the news dissemination way, cultivate a professional team for complex skills of journalism. Schools should attach importance to the cooperation between schools and off campus media, and actively provide students with a real media platform for students' professional practice and off campus practice. We should enable students to feel the real media communication environment in magazines, stations and other environments, to provide an environmental basis for students to better position themselves and enhance their professional skills. Several years learning in schools, students need to learn is not only a skill, but from the stage to behind the scenes from the production of news to the late, to be familiar with the whole process to truly in the news industry have good development, therefore, the high school should strengthen the students' basic ability the training for students' comprehensive quality promotion and lay a good foundation. Colleges and universities should also be aware of the actual situation of the media industry today, now the news gathering is no longer difficult, the difficulty is how to journalists in the multitude information to extract useful information and effective editing.

\subsection{Enrich Curriculum Content}

Under the prospect of media convergence, we need to transform journalism education goals from original trained journalists to different disciplines, so that news media people will have knowledge of economics, society, politics, history, philosophy and many other subjects. The biggest difference between professional journalists and citizen journalists is that they have the news vision and professional view. They have the spirit of humanity and criticism. They can identify and publish valuable news in large amounts of information, and bring great social value. The traditional journalism education pays attention to training practical talents and pays attention to the practical training of journalists. With the rapid development of media convergence and network technology, news media and the traditional education curriculum system under the integration of journalism needs, the traditional curriculum system must be improved, which is based on a multidisciplinary education including natural science, social science and humanities, to create journalism communication and excellent talents with the spirit and critical force. The media transformation brought by media convergence requires that colleges and universities should place emphasis on the cultivation of students' professional thinking ability and media convergence consciousness and team 
cooperation consciousness in the formulation of training objectives, and make the training plan specific and executable. In addition to the required courses of the journalism major, the general elective courses of other subjects are set up to give students more platform for hunting knowledge. We have a top priority in the teaching of technical courses, such as recording, shooting, and network. Scientific development of training programs to meet the needs of the media integration era of journalism should adjust the traditional curriculum, the gap between the traditional professional breakthrough, strengthen support training courses for the professional practice of students to adapt to the media convergence brings to the traditional journalism shock. In the context of media integration, colleges and universities should carry out the integration of departments and departments, and use the interdisciplinary to carry out more characteristic journalism teaching.

\subsection{Increase Practice Teaching}

The traditional journalism courses have a fine division of the specialty, and the classification education for TV, radio, newspaper and network specialties. This is obviously not adapted to the demand for media journalists in the context of media integration. With the continuous development of the integration and development of traditional media and new media, the core competitiveness of news media is not only about news gathering and dissemination, but also needs to be integrated and deeply excavated to enhance its quality and value. At the same time, the diversification of subdivision, audience demand media, accurately distinguish news market and realizing the media focus has become a new model of the new media era of news communication, news and information dissemination will be further extended to knowledge and services has become a new requirement on the news media era of media convergence. This puts forward higher requirements for the knowledge structure and professional level of news communication talents. A specialist journalism talent with expertise or professional background in a specific field will be in urgent need for the media in the era of media convergence. In the new situation, to change the traditional categories according to different media division course practices journalism courses, the curriculum should adapt to the development of media convergence, integration of news practice, the course of various media professional has stronger compatibility and openness, train more skilled talents for journalism. Therefore, journalism education should constantly innovate curriculum design, try to integrate journalism or media fusion major, and add mobile news, digital news, network news and fusion news courses. We realize the gradual transition from the traditional practice curriculum to the media integration to meet the needs of the complex media units for the complex talents.

\section{Conclusion}

Media integration has brought a great impact on the traditional news dissemination, and put forward higher requirements for the news and communication talents. To meet the needs of journalism in the context of media convergence, we must change the traditional form of journalism education and set up a training mode of journalism talents to meet the requirements of the development of media and media convergence. Only in this way can we cultivate more media talents with multiple media skills and comprehensive qualities for the news education to promote the healthy development of the journalism.

\section{References}

[1] Gao Xiaoyu, Sun Hua. MJC Education under Media Convergence: A Comparative Study between China and the US [J]. China Higher Education Research, 2015(8): 82-86+97.

[2] Cheng Zhongliang, Wang Yeming. Thoughts on Reshaping Journalism Education in the Era of Media Convergence [J]. Journal of Anqing Normal University (Social Science Edition), 2014, 33(2): 43-46.

[3] Zhang Yuan. Thinking of Journalism Education Philosophy in the Trend of Media Convergence [J]. Theory and Practice of Education, 2012, 32(27): 48-50. 
[4] Li Huajun, Zhang Wanning. The Development of Mobile News Apps in the Background of Media Convergence- Based on the Uses and Gratification of Youth Group [J]. Journal of Beijing Institute of Technology (Social Sciences Edition), 2018, 20(1): 165-172. 